\title{
Pertanggung Jawaban Pidana dan Kaitannya dengan Pertanggungjawaban Perdata Pelaku Penelantaran Rumah Tangga
}

\author{
Maryati $^{1}$, Usman ${ }^{2}$ \\ ${ }^{1}$ Fakultas Hukum Universitas Batanghari \\ Jalan Slamet Riyadi Broni Kota Jambi Telp: (0741) 65351 \\ ${ }^{2}$ Fakultas Hukum Universitas Jambi \\ Correspondence e-mail: maryati@unbari.ac.id, usman.marjamat@unja.ac.id
}

\begin{abstract}
Abstrak. Penelantaran rumah tangga pada khakekatnya termasuk ranah pertanggungjawaban perdata, namun dapat berimplikasi pada pertanggungjawaban pidana. Artikel ini bertujuan menjelaskan hubungan pertanggungjwaban perdata dan pidana pelaku penelantaran ruamah tangga. Pertanggungjawaban perdata pelaku penelantaran rumah tangga didasarkan pada kerugian akibat penelantaran rumah tangga, sehingga pelaku wajib mengganti kerugian. Peberian ganti rugi berdasarkan asas hukum bahwa kewajiban suami sesuai dengan kemampuannya. pertanggungjawaban pidana didasarkan pada terpenuhinya unsur actus reus dalam Pasal 9 UU KDRT, dan unsur mens rea berupa kesengajaan atau kealpaan dari pelaku. Pemenuhan tanggung jawab perdata pelaku penelantaran rumah pada khakehatnya menghilangkan sifat melawan hukum pelaku, sehingga seharusnya dapat menjadi dasar untuk menghentikan proses peradilan pidana, namun belum ada mekanisme hukum yang mengatur. Yang memungkinkan melalui lembaga pidana percobaan (Pasal 14a KUHP. Untuk itu diperlukan aturan terkait dengan keadilan restoratif dan penerapan asas ultimum remedium dalam aturan tentang perlidungan KDRT yang lebih mengutamakan pertanggungjawaban perdata.
\end{abstract}

Kata Kunci: pertanggungjawaban perdata, pertanggungjawaban pidana, Penelantaran rumah tangga

\begin{abstract}
The neglect of the household in its realm belongs to the realm of civil liability, but can have implications for criminal liability. This article aims to explain the relationship between civil and criminal liability for the neglect of the household. Civil liability of perpetrators of household neglect is based on losses due to neglect of the household, so the perpetrators are required to compensate. Peberian compensation based on the principle of law that the obligations of the husband in accordance with the ir abilities. Criminal liability is based on the fulfillment of the actus reus element in Article 9 of the Domestic Violence Act, and the mens rea element is intentional or negligent of the perpetrator. Fulfillment of civil liability perpetrators of neglect of the house in khakhatnya eliminate the offensive nature of the perpetrator, so that it should be the basis for stopping the criminal justice process, but there is no legal mechanism that regulates. That is possible through probationary criminal institutions (Article 14a $K U H P)$. For this reason, it is necessary to have rules related to restorative justice and the application of the principle of ultimum remedium in the rules on domestic protection that prioritize civil accountability.
\end{abstract}

Keywords: civil liability, criminal liability, household neglect

\section{PENDAHULUAN}

Rumah tangga merupakan kelompok terkecil dari tatanan sosial dalam masyarakat suatu bangsa. Meskipun demikian keberadaannya memiliki kontribusi penting dalam menentukan maju dan mundurnya suaru bangsa. Pembentukan rumah tangga, secara ideal digambarkan hukum perkawinan Indonesia dalam Undang-Undang No 1 Tahun 1974 Tentang Pekawinan (UU Perkawinan), yaitu "untuk membentuk keluarga (rumah tangga) yang bahagia dan kekal berdasarkan Ketuhanan Yang Maha Esa". Meskipun demikian tujuan ini tidak selalu dapat diwujudkan oleh suatu keluarga atau rumah tangga. Tidak jarang justru dalam rumah tangga terjadi kekarasan dalam berbagai bentuknya yang berakibat pada runtuhnya sendi-sendi rumah tangga. Persoalan ini cukup serius ditemu di Indonesia. Hal ini terlihat dari data Komisi Nasional Perempuan yang menyebutkan, yang menggambarkan masih tingginya angka kekerasan terhadap perempuan. Pada 2019 berjumlah 406.178. Data ini menunukkan peningkatan dibanding tahun 2018, yang berjumlah 348.466. dari jumlah tersebut, 71\% (9.637) merupakan kekerasan dalam rumah tangga $\left(\right.$ KDRT). ${ }^{1}$

Penelantaran rumah tangga merupakan satu bentuk dari KDRT. Modus KDRT ini dalam hukum Indonesia diatur Undang-undang No. 23 Tahun 2004 tentang Penghapusan Kekerasan Dalam Rumah Tangga (UU PKDRT). Berdasarkan undang-undang tersebut KDRT dapat dilakukan dengan berbagai cara, meliputi:

a. kekerasan fisik;

b. kekerasan psikis;

c. kekerasan seksual; atau

1 Komisi Nasional Perlindungan Perempuan, "Catatan Kekerasan Terhadap Perempuan Tahun 2018”. Komnas Premepuan, Jakarta, 2019., hlm. 1 
d. penelantaran rumah tangga.

Berbeda dengan konsep hukum KDRT, ${ }^{2}$ demikian juga konsep hukum kekerasan seksual, ${ }^{3}$ yang secara tegas dirumuskan. Konsep hukum penelantaran rumah tangga di dalam UU KDRT tidak secara tegas disebutkan. Pasal 9 ayat (1) UU KDRT hanya menyebutkan kreteria secara umum sebagai indikator penelatanran rumah tangga. Dikatakan menelantarkan orang dalam lingkup rumah tangganya, apabila menurut hukum yang berlaku baginya atau karena persetujuan atau perjanjian ia wajib memberikan kehidupan, perawatan, atau pemeliharaan kepada orang tersebut. Sedangkan yang bersangkutan tidak melaksanakan kewajibannya itu. Termasuk juga penelantaran keluarga berdasarkan Pasal 9 ayat (2) UU KDRT, yaitu setiap orang yang mengakibatkan ketergantungan ekonomi, yang dilakukan dengan cara membatasi dan/atau melarang untuk bekerja yang layak sehingga korban berada di bawah kendali orang tersebut.

Rumusan Pasal 9 UU KDRT, tentang konsep hukum penelantaran rumah tangga dalam pratiknya masih menyisakan banyak persoalan. Unsur kata wajib memberikan kehidupan, perawatan, atau pemeliharaan dalam Pasal 9 ayat (1) UU KDRT konsekuensinya adalah pelanggaran pidana bagi yang tidak memenuhi kewajibannya. Padahal pemberian kehidupan, perawatan, atau pemeliharaan sangat tergantung dari dua unsur, yaitu kemampuan dan kemauan. Pertama, adakalanya seorang kepala keluarga mampu, namun tidak mau memberikan kehidupan, perawatan, atau pemeliharaan. Kedua, kepala keluarga mau memberikan kehidupan, perawatan, atau pemeliharaan, namun tidak memiliki kemampuan. Dalam hal yang pertama maka layak dikualifikasikan sebagai tindak pidana. Namun bagaimana dengan kategori yang kedua? Terkait dengan kempuan juga bersifat relatif, bagaimana jika hanya mampu memenuhi kewajiban sebagian saja?

Penelantaran rumah tangga pada khakekatnya merupakan persolan tanggungjawab kepala keluarga dalam memberikan kehidupan, perawatan, atau pemeliharaan kepada orang anggota keluarganya. Oleh karena itu terkait dengan variabel kemampuan bertanggungjawab dari kepala keluarga untuk memenuhi kewajibannya tersebut. Tanggungjwab ini merupakan ranah pertanggungjawaban perdata. Meskipun demikian, dalam hal kepala keluarga melalaikan kewajibannya tersebut, dapat berimplikasi pada pertanggungjawaban pidana. ${ }^{4}$ Sehubungan dengan permasalahn tersebut, maka masalah yang akan dikaji adalah" 1) bagaimana batas-batas pertangungjawab perdata dan pertanggungjawaban pidana pelaku penelantaran ruamah tangga? 2) bagaimana hubungan antara pertanggunjawaban perdata dan pertanggungjawaban pidana dalam kasus penelataran rumah tangga?.

\title{
HASIL DAN PEMBAHASAN
}

\section{Pertanggungjawaban Perdata Pelaku Penelantaran Rumah Tangga}

Konsep hukum pertanggungjawaban perdata terkait dengan konsep hukum perbuatan melawan hukum. Dalam KUH Perdata, tidak dirumuskan secara tegas makna perbuatan melawan hukum. Oleh karena itu untuk mengetahuinya dapat diketahui melalui penafsiran Pasal 1365 dan Pasal 1336 KUHPerdata. ${ }^{5}$ Dari penafsiran pasal tersebut, dianggap sebagai perbuatan melawan hukum apabila memenuhi unsur-unsur : perbuatan melawan hukum; kesalahan; kerugian; dan hubungan sebab akibat antara kerugian dan perbuatan. ${ }^{6}$

Menurut Moegni Djojodirdjo, pengertian perbuatan melawan hukum dalam yurisprudensi Hoge Raad (HR) Belanda, seiring perkembangan waktu mengalami perkembangan. Dalam putusan HR sebelum tahun 1919, perbuatan melawan hukum dimaknai secara terbatas pada tiap perbuatan yang bertentangan dengan hak orang lain yang timbul karena undang-undang atau tiap perbuatan yang bertentangan dengan kewajiban hukumnya sendiri yang timbul dari peraturan. Namun dalam putusan HR setelah tahun 1919, dimaknai secara luas, meliputi perbuatan atau kealpaan atau bertentangan dengan hak orang lain atau bertentangan dengan kewajiban hukum pelaku atau bertentangan dengan kesusilaan atau kepatutan dalam masyarakat, baik terhadap orang lain maupun benda. ${ }^{7}$

Konsep pertanggungjawaban dalam KUH Perdata, dirumuskan bahwa tiap orang tidak hanya bertanggungjawab terhadap kerugian yang disebabkan karena perbuatannya sendiri, tetapi meliputi juga kerugian yang ditimbulkan karena perbuatan orang-orang yang menjadi tanggungannya, termasuk juga kerugian akibat barangbarang yang berada di bawah pengawasannya. Dengan demikian khakekat perbuatan melawan hukum adalah bertentangan dengan kewajiban hukum si pelaku, atau melanggar hak subjektif orang lain, atau melanggar kaidah tata

\author{
${ }^{2}$ Lihat Pasal 1 angka 1 UU KDRT. \\ ${ }^{3}$ Lihat Penjelasan Pasal 8 UU KDRT. \\ ${ }^{4}$ Lihat Pasal 49 UU KDRT. \\ ${ }^{5}$ Pasal 1365 KUHPerdata. \\ ${ }^{6}$ Lihat Djaja S. Meliala, Hukum Perdata dalam Perspektif BW, Revisi Keempat, Nuansa Aulia, Bandung, 2014 , hlm.
}

\footnotetext{
${ }^{7}$ Moegni Djojodirdjo, Perbuatan Melawan Hukum, Pradnya Paramita, Jakarta, 1982, hlm. 25-27.
} 
susila (goede zeden), atau bertentangan dengan azas kepatutan, ketelitian serta sikap hati-hati dalam pergaulan hidup masyarakat. $^{8}$

Berdasarkan konsep perbuatan melawan hukum sebagaimana disebutkan sebelumnya, dihubungkan dengan penelantaran rumah tangga, apakah dapat dikatakan sebagai perbuatan melawan hukum sehingga dapat dituntut pertanggungjawaban perdata? Dalam kaitannya dengan penelantaran rumah tangga, Pasal 9 ayat (1) UU KDRT, pada khakekat adalah pengabaian terhadap wajib memberikan kehidupan, perawatan, atau pemeliharaan kepada orang tersebut. Berkenaan dengan kewajiban suami, Pasal 34 ayat (1) UU Perkawinan, mewajibkan suami melindungi isterinya dan memberikan segala sesuatu keperluan hidup berumah tangga sesuai dengan kemampuannya.

Sehubungan dengan kewajiban suami dalam rumah tangga, Pasal 80 Instruksi Presiden Republik Indonesia Nomor 1 Tahun 1991 Tentang Kompilasi Hukum Islam (Kompilasi Hukum Islam), pertama, wajib melidungi isterinya dan memberikan segala sesuatu keperluan hidup berumah tangga sesuai dengan kemampuannya. Kedua, wajib memberikan pendidikan agama kepada isterinya dan memberi kesempatan belajar pengetahuan yang berguna dan bermanfaat bagi agama, nusa dan bangsa.

Dalam kaitannya antara Pasal 9 ayat (1) UU KDRT dengan Pasal 34 ayat (1) UU Perkawinan, dan Pasal 80 Kompilasi Hukum Islam, maka dapat ditafsirkan, bahwa kewajiban yang tidak boleh dilanggar Pasal 9 ayat (1) UU KDRT, yaitu kewajiban memberikan kehidupan, perawatan, atau pemeliharaan. Dalam dengan Pasal 34 ayat (1) UU Perkawinan, dan Pasal 80 Kompilasi Hukum Islam. Penelantaran terhadap kewajiban yang diatur dalam ketentuan tersebut merupakan perbuatan melawan hukum, sehingga ketika menimbulkan kerugian menjadi kewajiban kepada suami memberikan pemenuhan terhadap semua kewajiban yang dilalaikan.

Secara teoretis, pertanggungjawaban perdata bersumber dari perbuatan melawan hukum atau wanprestasi. Di sisi lain, karena perbuatan tersebut memenuhi usur-unsur yang tertuang dalam pasala 1365 KUHPerdata, maka merupakan merupakan perbuatan melawan hukum. Oleh karena itu pertanggungjawaban pelaku penelantaran rumah tangga dilihat dari sisi KUH Perdata dikategorikan sebagai pertanggungjawaban langsung berdasarkan pasal 1365 KUHPerdata, yaitu setiap perbuatan melanggar hukum yang berakibat pada kerugian orang lain, wajib bagi orang yang menimbulkan kerugian itu mengganti kerugian tersebut. Demikina pula atas dasar pasal 1366 KUHPerdata, bahwa setiap orang bertanggungjawab atas kerugian yang disebabkan perbuatan-perbuatan, termasuk juga atas kerugian yang disebabkan kelalaian atau kecerobohannya. Dengan demikian maka seorang kepala keluarga dalam yang melalaikan kewajibannya yang berakubat kerugian nyata pada anggota keluarga, wajib memikul tanggung jawab perdata secara langsung. Dalam hal pelaku penelantaran keluarga dapat memenuhi kewajibannya tersebut, atau sampai pada batas-batas kemampuannya, maka pada prinsipnya kerugian yang diderita oleh anggota rumah tangga sudah dapat ditebus lunas. Sehingga tanggung jawab perdata pelaku dapat dipenuhi. Namun dalam hal mengabaikan kewajiban ganti rugi tersebut maka berakibat pada pelanggaran hukum pidana.

\section{Pertanggungjawaban Pidana Pelaku Pelaku Penelantaran Rumah Tangga}

Norma yang melarang menelantarkan orang dalam lingkup rumah tangganya di dalam UU KDRT diarumuskan dalam Pasal 9. Sedangkan ancaman pidana terhadap larangan tersebut diatur dalam Pasal 49.

Unsur Pasal 9 ayat (1) adalah sebagai berikut:

a. Setiap orang

b. menelantarkan orang

c. dalam lingkup rumah tangganya,

d. padahal menurut hukum yang berlaku baginya atau karena persetujuan atau perjanjian ia wajib memberikan kehidupan, perawatan, atau pemeliharaan kepada orang tersebut.

a. Setiap orang

Sedangkan Unsur Pasal 9 ayat (2) adalah sebagai berikut:

b. yang mengakibatkan ketergantungan ekonomi

c. dengan cara membatasi dan/atau melarang untuk bekerja yang layak di dalam atau di luar rumah

d. sehingga korban berada di bawah kendali orang tersebut.

Ancaman pidana terhadap pelanggaran Pasal 9 ayat ditentukan dalam Pasal 49 dengan ancaman pidana penjara paling lama 3 (tiga) tahun atau denda paling banyak Rp15.000.000,00 (lima belas juta rupiah),

Pertanggungjawaban pidana pada dasarnya adalah diteruskannya ancaman pidana yang objektif dalam rumusan tindak pidana secara subjektif kepada seseorang yang bersalah melakukan tindak pidana. Atau dengan kata lain Pertanggungjawaban pidana adalah pengenaan pidana yang dianacamkan dalam undang-undang kepada orang yang bersalah melanggar undang-undang tersebut. Dalam konteks pertanggungjawaban pidana pelaku penelantaran

${ }^{8}$ Velliana Tanaya, "Rekonstruksi Asas Perbuatan Melawan Hukum dalam Sengketa Konsumen”, Jurnal Ilmu Syariah dan Hukum Asy-Syir'ah Vol.47 No.1 Tahun 2013 
rumah tangga, maka diterapkannya ancaman pidana dalam Pasal 49 UU KDRT kepada pelaku pelanggaran Pasal 49 jo pasal 9 UU KDRT.

Dalam hukum pidana perantanggungjawaban bukan hanya digantungkan pada perbuatannya, tetapi juga didasarkan pada kesalahannya. Menurut Sudarto untuk dapat mempidana seseorang, tidak cukup karena seseorang telah melakukan perbuatan yang bertentangan dengan hukum. Selain pembuatnya memenuhi unsur tindak pidana masih perlu adanya syarat, bahwa orang yang melakukan perbuatan itu mempunyai kesalahan. ${ }^{9}$ Demikian pula menurut Roeslan Saleh. Karena dalam pengertian tindak pidana tidak termasuk di dalamnya pertanggungjawaban. Tindak pidana hanya menunjuk kepada perbuatan yang dilarang. Apakah pelaku kemudian dipidana, tergantung apakah pelaku mempunyai kesalahan atau tidak. Apabila pelaku tindak pidana mempunyai kesalahan, maka dapat dipidana. ${ }^{10}$

Pemisahan antara konsep tindak pidana dan pertanggungjawaban pidana tersebut berarti menganut paham dualistis. Konsep ini juga digunakan dalam rancangan KUHP. Antara tindak pidana dan pertanggungjawaban pidana dipisahkan. Dipidana seseorang actus reus dan mens rea). ${ }^{11}$ Berdasarkan konsep ini seorang yang melakukan tindak pidana tidak selalu harus dipidana. Tergantung apakah dalam melakukan tindak pidana pelaku memiliki kesalahan.

Asas ini tiada pidana tanpa kesalahan tidak dirumuskan secara tegas di dalam KUHP yang berlaku saat ini, namun menjadi dasar dalam pertanggungjawaban pidana. Pengaturan asas tiada pidana tanpa kesalahan baru dirumuskan dalam Pasal 6 ayat 2 UU No. 4 Tahun 2004 tentang Kekuasaan Kehakiman. Dalam perkembangan politik hukum pidana Indonesia, asas ini dirancang dalam RUU KUHP tahun 2019, dalam asas tiada pidana tanpa kesalahan dirumuskan Pasal 36.

Berkenaan dengan asas tersebut, maka perlu dijelaskan makna kesalahan, yaitu adanya hubungan antara batin dengan perbuatan yang dilakukan, yang dapat berbentuk kesengajaan atau kealpaan. ${ }^{12}$ Pasal 36 RUU KUHP tahun 2019, dirumuskan bahwa setiap Orang hanya dapat dimintai pertanggungjawaban atas Tindak Pidana yang dilakukan dengan sengaja atau karena kealpaan. Suatu perbuatan jika dikehendaki oleh pelaku, maka merupakan kesengajaan. Sebaliknya jika perbuatan itu tidak dikehendaki, maka merupakan kealpaan. ${ }^{13}$

Berdasarkan uraian sebelumnya maka untuk dapat dipidana pelaku penelentaran rumah tangga, selain harus memenuhi setiap unsur dari tindak pidana sebagaimana diuraikan dalam Pasal 9 UU KDRT sebagai unsur actus reus, pelaku juga harus memiliki unsur kesalahan sebagai unsur mens rea. Yaitu pelaku melakukan pelanggaran tersebut dilakukan dengan sengaja atau lalai. Persoalnnya bagaimana jika terjadi pelanggaran namun dikarenakan pelaku tindak memiliki kemampuan untuk emmenuhi kewajibannya? Berdasarkan Pasal 34 ayat (1) UU Perkawinan dan Pasal 80 Kompilasi Hukum Islam, dengan menggunakan asas hukum "kewajiban suami melidungi isterinya dan memberikan segala sesuatu keperluan hidup berumah tangga sesuai dengan kemampuannya”. Berdasarkan asas ini maka seorang yang tidak memenuhi kewajibannya karena tidak mampu maka tidak dapat dipidana.

\section{Hubungan Pertanggungjawaban Peradata dan Pidana Pelaku Penelantaran Rumah Tangga,}

Pada dasarnya urusan rumah tangga merupakan urusan lingkup keperdataan, yaitu menyangkut kewajiban kepala keluarga terhadap anggota keluagranya, namun urusan tesersebut dapat bergeser menjadi urusan pidana ketika kewajiban perdatanya diabaikan. Menjadi soal kemudian, bagaimana dalam hal telah terjadi pelanggaran Pasal 49 jo Pasl 9 KDRT, apakah meknisme pemenuhan tanggungjwab perdata masih dapat dilakukan, sehingga tangung jawab pidana tidak diterapkan?

Dalam konsep pemidanaan digunakan asas hukum, bahwa pidana merupakan alteratif terakhir. Dalam kaitan ini menurut Sudikno Mertokusumo azas tersebut menghendaki bahwa dalam penegakan hukum, hukum pidana merupakan upaya terakhir. Sebalinya asas primum remedium, dalam penegakan hukum, maka hukum pidana dijadikan pilihan utama. ${ }^{14}$ Sehubungan asas hukum tersebut persoalnna apakah asas ini tepat digunakan untuk dalam perkara penelatantaran rumah tangga?

${ }^{9}$ Lihat Muladi dan Dwidja Priyatno, Pertanggungjawaban Pidana Korporasi, Cetakan ke-4/Edisi Revisi, Kencana Prenadamedia Group, Jakarta, 2013, hlm. 69

${ }^{10}$ Roeslan Saleh, Perbuatan Pidana dan Pertanggungjawaban Pidana; Dua Pengertian Dasar dalam Hukum Pidana, Jakarta: Aksara Baru, 1983, hlm. 75.

${ }^{11}$ Septa Candra Pembaharuan Hukum Pidana;Konsep Pertanggungjawaban Pidana Dalam Hukum PidanaNasional Yang Akan Datang, Jurnal Cita Hukum, No 1 Volume 1 Tahun 2013, hlm. 43.

${ }^{12}$ Eddy O.S. Hiariej, Prinsip-Prinsip Hukum Pidana. Yogyakarta : Chhaya Atmapustaka, 2016, hlm. 159.

13 Ibid.

${ }^{14}$ Lihat Kukuh Subyakto, “Azas Ultimum Remedium Ataukah Azas Primum Remedium Yang Dianut Dalam Penegakan Hukum Pidana Pada Tindak Pidana Lingkungan Hidup Pada Uu Nomor 32 Tahun 2009 Tentang Perlindungan Dan Pengelolaan Lingkungan Hidup”, Jurnal Pembaharuan Hukum, Volume II No. 2 Mei - Agustus 2015, hlm 211. 
Berdasarkan asas ultimum remedium, maka penerapan pindana penjara atau denda sehahurnya sebagai upaya terakhir dalam hal terjadi pelanggaran Pasal 49 jo Pasal 9 KDRT. Dalam kasus semacam ini yang diutamakan adalah pemenuhan tanggung jawab perdata sesuai dengan batas-batas kemampuannya. Dalam hal menolak tanggungjawab tersebut barulah dapat dekenakan pidana penjara atau denda. Penerapan asas ultimum remdium lebih baik dalam penanganan perkara penelantaran rumah tangga, dari pada menggunakan asas primum remedium. Karena kedua jenis pidana itu tidak berdampak langsung pada korban. Pidana denda yang menerima adalah negara bukan korban. Apa lagi jiak dijatuhkan pidana penjara, malah melumpuhkan pelaku untuk mencari nafkah yang dibutuhkan untuk kemungkinan dapat memenuhi kewajiban rumah tangga.

Persoalan kemudian apakah pemenuhan kewajiban perdata pelaku penelantaran rumah tangga dapat menghentikan proses peradilan pidana? Dalam sistem hukum pidana Indonesia, penyelesaian perkara pidana dilakukan melalui mekanisme sistem peradilan pidana. Oleh karena itu pada dasarnya perkara pidana, termasuk tindak pidana penelantaran rumah tangga secara normative tidak dapat diselesaikan melalui mekanisme di luar sistem peradilan pidana. ${ }^{15}$ Berbeda jika UU KDRT menggunakan konsep keadilan restoratif dalam penyelesaiannya, sebagaimana dalam sistem peradilan anak, UU KDRT juga tidak diatur secara khusus tentang kemungkinan penyelesaian tindak pidana penelantaran rumah tangga melalui mekanisme di luar peradilan pidana. Oleh karena itu dalam kasus tindak pidana penelataran rumah tangga harus ditempuh melalui peradilan pidana, dan palaku tindak pidana harus bertanggungjawab secara pidana.

Dalam kaitannya pertanggungjawaban perdata yang sudah dipenuhi oleh palaku, maka dalam hukum pidana Indonesia, kasus semacam ini yang mungkin dilakukan adalah melakukan penerapan lembaga pidana bersyarat. Hakim pat menjatuhkan pidana percobaan, sebagaiman diatur dalam Pasal 14a KUHP. ${ }^{16}$ Karena ketika kewajiban palaku penelantaran rumah tangga dipenuhi, maka pidana yang sudah ditetapkan hakim tidak harus dijalani oleh terpidana. Sehingga dalam kasus semacam ini pada dasarnya juga masih mengikuti asas ultimum remedium.

Sehubungan dengan permaslahan kekosongan hukum tersebut, maka perlu diatur tentang tentang keadilan restoratif sebagai mekanisme penyelesaian perkara KDRT pada umumnya, dan khususnya kasus penelantaran rumah tangga. Karena pada khakekatnya melalui keadilan restoratif maka akan lebih dapat menekan kerugian yang lebih besar sebagai akibat proses peradilan system peradilan pidana, seperti konflik yang lebih dalam antara pelaku dan korban serta pemidanaan yang justru melepaskan tanggung jawab perda pelaku.

\section{SIMPULAN}

1. Pertanggungjawaban pelaku penelantaran rumah tangga dilihat dari sisi KUH Perdata dapat dikategorikan sebagai pertanggungjawaban langsung berdasarkan pasal 1365 dan pasal 1366 KUHPerdata . Berdasarkan ketentuan tersebut maka seorang kepala keluarga yang mengakibatkan kerugian nyata pada anggota keluarga, wajib memikul tanggung jawab perdata secara langsung untuk mengganti rugi. Sedangkan dari sisi hukum pidana, untuk dapat dipidana pelaku penelentaran rumah tangga, selain harus memenuhi setiap unsur dari tindak pidana sebagaimana diuraikan dalam Pasal 9 UU KDRT sebagai unsur actus reus, pelaku juga harus memiliki unsur kesalahan sebagai unsur mens rea, yaitu penelantaran keluarga dilakukan dengan sengaja atau karena kelalaian. Dalam hal pelanggaran dikarenakan pelaku tindak memiliki kemampuan untuk memenuhi kewajibannya, maka berdasarkan Pasal 34 ayat (1) UU Perkawinan dan Pasal 80 Kompilasi Hukum Islam, deengan menggunakan asas hukum kewajiban suami sesuai dengan kemampuannya, maka seorang seseorang itu tidak dapat dipidana.

2. Ada hubungan antara tanggung jawab perdata dan tanggung jawab pidana pelaku penelantaran ruamah tangga, di mana dengan adanya pemenuhan kewajiban perdata, maka sifaat melawan hukum menjadi hilang. Oleh karena itu seharusnya dapat menjadi dasar untuk menghentikan proses peradilan pidana pelaku penelantaran rumah tangga. Namun karena UU KDRT belum menggunakan konsep keadilan restoratif, maka berdsarkan hukum pidana positif yang mungkin dilakukan adalah hakim menjatuhkan pidana percobaan, sebagaiman diatur dalam Pasal 14a KUHP. Karena ketika kewajiban palaku penelantaran rumah tangga dipenuhi, maka pidana yang sidah ditetapkan hakim tidak dijalani. Kedepan diperlukan aturan terkait dengan keadilan restoratif dan penerapan asas ultimum remedium dalam aturan tentang penghapusan KDRT yang lebih mengutamakan pertanggungjawaban perdata dari pada pertanggungjawaban pidana.

${ }^{15}$ Usman dan Andi Najmi, "Mediasi Penal di Indonesia: Keadilan, Kemanfaatan, dan Kepastian Hukumnya”, Undang: Jurnal Hukum, ISSN 2598-7933 (online); 2598-7941 (cetak)

Vol. 1 No. 1 (2018): 65-83, DOI: 10.22437/ujh.1.1.65-8, hlm.66.

${ }^{16}$ Lihat Pasal 14a ayat (1) KUHP: 


\section{DAFTAR PUSTAKA}

Clara Yunita Ina Ola, Khoirul Huda, Andika Persada Putera, "Tanggung Jawab Pertanggungjawaban Perdata Pelaku Penelantaran Rumah TanggaPidana, Perdata Dan Administrasi Asisten Perawat Dalam Pelayanan Kesehatan Desa Swadaya", Legality, ISSN: 2549-4600, Vol.25, No.2, September 2017- Februari 2018, hlm. 134-14672

Djaja S. Meliala, Hukum Perdata dalam Perspektif BW, Revisi Keempat, Nuansa Aulia, Bandung, 2014.

Eddy O.S. Hiariej, Prinsip-Prinsip Hukum Pidana. Yogyakarta : Chhaya Atmapustaka, 2016.

Komisi Nasional Perlindungan Perempuan, "Catatan Kekerasan Terhadap Perempuan Tahun 2018". Komnas Premepuan, Jakarta, 2019.

Kukuh Subyakto, "Azas Ultimum Remedium Ataukah Azas Primum Remedium Yang Dianut Dalam Penegakan Hukum Pidana Pada Tindak Pidana Lingkungan Hidup Pada Uu Nomor 32 Tahun 2009 Tentang Perlindungan Dan Pengelolaan Lingkungan Hidup”, Jurnal Pembaharuan Hukum, Volume II No. 2 Mei - Agustus 2015.

Moegni Djojodirdjo, Perbuatan Melawan Hukum, Pradnya Paramita, Jakarta, 1982, hlm. 25-27.

Muladi dan Dwidja Priyatno, Pertanggungjawaban Pidana Korporasi, Cetakan ke-4/Edisi Revisi, Kencana Prenadamedia Group, Jakarta, 2013.

Roeslan Saleh, Perbuatan Pidana dan Pertanggungjawaban Pidana; Dua Pengertian Dasar dalam Hukum Pidana, Jakarta: Aksara Baru, 1983.

Romli Atmasasmita, Asas-asas Perbandingan Hukum Pidana, Cetakan Pertama Jakarta: Yayasan LBH, 1989.

Septa Candra Pembaharuan Hukum Pidana;Konsep Pertanggungjawaban Pidana Dalam Hukum PidanaNasional Yang Akan Datang, Jurnal Cita Hukum, No 1 Volume 1 Tahun 2013.

Usman dan Andi Najmi, "Mediasi Penal di Indonesia: Keadilan, Kemanfaatan, dan Kepastian Hukumnya", Undang: Jurnal Hukum, ISSN 2598-7933 (online); 2598-7941 (cetak) Vol. 1 No. 1 (2018): 65-83, DOI: 10.22437/ujh.1.1.65-8, hlm.66.

Velliana Tanaya, "Rekonstruksi Asas Perbuatan Melawan Hukum dalam Sengketa Konsumen”, Jurnal Ilmu Syariah dan Hukum Asy-Syir'ah Vol.47 No.1 Tahun 2013.

Yul Ernis, "Diversi Dan Keadilan Restoratif Dalam Penyelesaian Perkara Tindak Pidana Anak di Indonesia (Diversion And Restorative Justice In Case Settlement Of Juvenile Justice System In Indonesia)," Jurnal kebijakan Hukum, Volume 10 No. 2 Tahun 2016., hlm. 163.

\section{Peraturan:}

Kitab Undang-Undang Hukum Pidana

Kitab Undang-Undang Hukum Perdata

Undang-Undang Republik Indonesia Nomor 23 Tahun 2004 Tentang Penghapusan Kekerasan Dalam Rumah Tangga

Rancangan Undang-Undang KUHP Indonesia tahun 2019 